\title{
ON AN IMPROVED METHOD OF TAKING OFF THE WASTE GAS FROM OPEN-TOPPED BLAST FURNACES.
}

By Mr. GeORGE aDdeNBRoOKE, of Darlaston.

The utilisation of the Waste Gas from Blast Furnaces has now become not only an accomplished fact but a great commercial success, and consequently an important part of furnace management. This gas, or rather mixture of gases, issues in large quantities from all the interstices between the last charge of materials in the furnace throat; and it passes off with such rapidity as to prevent a sufficient mixture of air taking place to render it inflammable until it has risen to some little height above the top of the materials in the furnace mouth. As soon however as this mixture of air takes place, a very considerable portion of the gas is consumed, in the case of the ordinary open-topped furnaces that do not utilise the waste gas. This combustion develops a great amount of heat; and the question therefore arises, how can the waste gas be made further useful, without in any way injuring the yield, the working of the furnace, or the quality of the iron made; for if any injury were occasioned in either of the above respects by taking off the waste gas, the utilisation of the gas ought certainly not to be attempted. It is evident that there must always be an escape of surplus gas from the top of the materials in the furnace throat, from the consideration that the heat in the lower part of the furnace distils off the gas from the fuel in the upper part; and this gas, not meeting with a supply of oxygen inside the furnace, passes up unconsumed to the furnace mouth, where upon mixing with the external air it burns away to waste, unless taken off previously in order to be usefully burnt elsewhere. 
The utilisation of the waste gas has been extensively carried out in two different modes, each capable of being applied and worked in several different ways. The one mode is known as the Close-Top system, and the other as the Open-Top system. Till the last few years however the writer believes that in no case was the waste gas successfully utilised in Staffordshire, though this had been effected a good many years previously in some other districts. The chief reasons for this continued waste of the gas in Staffordshire may be found in the cheapness of engine fuel, causing the mistaken idea to be entertained that it was cheaper to burn the slack under the boilers than to go to the expense of saving an article which would not be saleable; and also in the great dislike that all connected with the working of furnaces have to any considerable change in system.

The writer's attention was particularly called to the subject of utilising the waste gas from blast furnaces about five years ago, when he was engaged with others in examining the subject, and visited for the purpose many works where the utilisation was carried on at one or more of the furnaces. The decided opinion then arrired at was that the waste gas ought certainly to be utilised, and for the following reasons:-namely, that a furnace would work to better yield where the gas was utilised, and with greater regularity as to the quality of iron made; and that there would be a very considerable saving in repairs to hot-blast stoves and boilers by heating these with the waste gas, together with greater regularity in the heat and pressure of the blast, because of a more even temperature being maintained under the boilers and in the stoves; while there would also be a considerable saving in wages, and the men would be made more regular in charging the furnace.

The principle upon which the waste gas is taken off in the case of the close-topped furnaces is that, by keeping the furnace top closed, the gas must necessarily pass away through any openings which are made for its escape, and may thus be made to travel even to a distance of more than a quarter of a mile from the furnace, as is done at the Dowlais Iron Works. In the open-topped furnaces the idea is that, after the gas has done very nearly all its work in the 
furnace, on arriving within about 5 feet of the top of the materials in the furnace mouth the greater part can be drawn off from the furnace by applying a mild suction, and employed to advantage for heating purposes elsewhere; at the same time, as no considerable amount of force is used for drawing off the gas, either by the suction of a chimney or otherwise, all surplus gas generated in the furnace beyond the amount drawn off escapes at the open top of the furnace, by passing up through an average of $3 \frac{1}{2}$ feet depth of charged materials above the point of taking off the gas.

The open-topped plans of taking off the waste gas may here be divided into two classes :- those taking off the gas at a less depth than 5 feet below the top of the materials in the furnace throat; and those taking it off below that level. In the former the gas is taken off with due regard to the effect on the yield and working of the furnace; while in the latter the utilisation of the gas is made the chief object.

In order to carry out the utilisation of the gas without risk of interfering with the successful working of the furnace, it is of very great consequence not to take off the whole of the gas, but to leave a certain portion always to escape at the furnace mouth, so that it may continue the process of preparing the newly charged materials, and begin to dry and warm them immediately upon their being charged, and also prevent any downward current of air taking place from the furnace top. Such a downward current of air must necessarily take place frequently, where the whole of the gas is drawn off; as the chimney power requisite for this purpose would be quite sufficient to draw down the air through the average depth of $3 \frac{1}{2}$ feet of materials in the furnace throat above the gas openings, at any time when there was not an ample supply of gas to be drawn off. The result would then be that where the ascending gas and the descending air met in the furnace a bright flame would be produced, which taking place amongst the fuel must occasion a very serious loss, by causing combustion of the fuel before it reaches the part of the furnace where its combustion is useful; and it appears doubtful whether fuel thus once lighted would not continue 
smouldering the whole of the way down in the furnace. On the other hand if the fuel is properly covered in the upper part of the furnace by a sufficient depth of materials, so as to be protected from the air, the writer doubts whether it will begin to burn till it reaches the zone of fusion, where it then changes from a mere highly heated state to one of active combustion caused by the presence of air supplied from the tuyeres. The writer believes that in the fact of covering up the fuel, without ignition being allowed to take place, lies one of the chief sources of saving in the yield of the fuel; and he considers that it is this alone in the close-topped furnace, which to a very great extent makes up for the loss of yield of fuel that must inevitably result from the use of the close-topped system with its consequent back pressure. This saving however is more than counterbalanced by the fact that neither drying nor warming nor any other preparation of the materials can be carried on in the close-topped furnace except by the heat of the gas coming up from below.

Were it not for the back pressure produced in the furnace by a closed top, this system would doubtless work to a much better yield than the open top; but the entire prevention by the closed top of any drying or warming of the materials taking place until they have descended some distance within the furnace is a serious objection in the writer's opinion to the close-topped plan; whilst on the other hand in a well worked open-topped furnace the preparation of the materials begins at once upon their being charged. Moreover there is no way of so regulating the "driving" of a furnace or rate of descent of the materials in the interior as that in every hour the furnace shall take the same quantity of blast; but whenever the steam pressure happens to rise above the average, cansing the engine to force more blast into the furnace, or whenever the materials happen to lie more open in the furnace or to be drier, an increased driving of the furnace will be occasioned, which will give an increased production of gas to pass off from the furnace. As this larger quantity of gas has in the close-topped furnace to pass off through the same openings which previously carried off a smaller quantity, the result must be an increase of the back pressure in the furnace; 
whereas with an open top the surplus gas readily escapes at the mouth of the furnace, without producing any back pressure inside the furnace. Another objection to the closed top is that the pressure coming from the lower part of the furnace will carry off with it from the furnace more dust than would be drawn off by suction.

The desideratum in the atilisation of the blast furnace waste gas appears therefore to the writer to be an open top where the fuel can be buried or covered, without its being ignited to any material extent either by the escaping gas, or worse still by the gas being drawn off so completely from the furnace throat that air is drawn down also through the materials, causing a hidden fire to be raging beneath the surface of the materials while everytbing seems to be going on well. The writer has indeed frequently seen the gas drawn off so completely that a man could walk inside the mouth of a large furnace while the blast was on; but experience shows that such a state of the furnace top is altogether wrong, and if ever it occurs the main gas valve ought at once to be closed sufficiently to ensure some gas passing off at the furnace top, in order to begin the preparation of the materials and prevent any downward current of air.

The level at which the gas is taken off from the furnace is in the writer's opinion a most important point, as in effect the working height of the furnace nearly terminates at the level where the gas is taken off. The most satisfactory working that the writer has known of a blast furnace has been where the gas was partially and not wholly taken off and at a depth of $4 \mathrm{ft}$. 6 ins. below the top of the materials. In one case that came under his experience, one of Darby's bells was used very successfully for a considerable time, taking off the gas at a depth of 4 ft. 6 ins. below the top; but when it became necessary to change it, the new bell was inserted to a depth of $5 \mathrm{ft}$. 6 ins., in order to give the fillers a little more range of level; this was however found to work so much less satisfactorily that it was altered back again to the original depth of 4 ft. 6 ins. 
The very great sensitiveness of a furnace to the least lowering of its working height is undoubtedly the cause of more than one half of the mottled and white iron that is made where grey forge or forge iron was expected. The change is usually caused by delay in filling, most frequently at night, when the men often neglect their work and allow the furnace to drive, so that the surface of the materials is lowered a considerable distance; and the effect is then observed about three casts later by the production of mottled or white iron. The worst consequence of this neglect is that the furnace manager then finding white iron made probably alters the burden at once in order to correct the fault; and after charging it up to the next casting time with either less ore or more fuel, he probably finds this next cast all right, and therefore alters the burden back again; but in another cast or two comes the iron made from the lighter burden, rather too grey to suit the purposes it is wanted for. With a closed top there can be no check upon irregularity in flling, day or night, except by constantly watching the filling. But in an open-topped furnace where the gas is taken off through openings not lower than 5 feet below the top of the materials, if the filling were delayed more than half an hour, the greater portion of the gas would begin to escape at the furnace mouth instead of being drawn off through the gas openings, as the surface of the materials would be lowered nearly to the level of the gas openings. The fillers' neglect would then be detected by an increased flame from the furnace mouth, and by the supply of gas to the boilers and hot-blast stoves falling short; and they would be recalled to their duty by the risk of all coming to a standstill from stoppage of the blowing engine.

This great sensitiveness of blast furnaces as to being kept charged full appears to suggest strongly the doubt whether the Staffordshire furnaces are now as high as the fuel would allow of their being worked profitably; and whether a gain of yield would not be found to result from raising the furnaces. The present height of from 40 to 50 feet in Staffordshire has been inereased in the Cleveland district up to 80 feet and more, and it is considered the limit of height has not yet been arrived at in that district. 
There is no doubt that the Staffordshire fuel would not stand any very considerable increase of height, on account of its friability; but it would at least be desirable to ascertain by trial whether some increase of height would not be beneficial.

The result of the previous enquiries in which the writer was engaged as to the best mode of utilising the waste gas from blast furnaces was the adoption of the open-topped plan with Darby's bell inserted in the neck of the furnace to a depth of $4 \mathrm{ft} .6$ ins. below the surface of the materials; and the writer has much pleasure in acknowledging the good service rendered in connection with the South Staffordshire iron district by the introduction of this plan to notice in the valuable paper read upon the subject at a former meeting of the Institution five years ago, (see Proceedings Inst. M. E., 1860, page 251). This plan was applied to two furnaces at the writer's works at Darlaston; and in carrying it out the special points attended to were to provide a large gas main, a large chimney, and large flues to the chimney. For this purpose the gas mains were made $5 \mathrm{ft}$. diameter, the chimney $10 \mathrm{ft}$. diameter inside thronghout with a height of 160 feet, and the main flues to the chimney very large, $5 \mathrm{ft}$. high to the crown of the arch and $4 \mathrm{ft}$. 6 ins. wide; and experience has shown that these dimensions are none too large.

The two furnaces continued at work on this system till September 1864, when the heary cost of repairs and renewals with the consequent stoppages and loss in wages led the writer to design the plan to be described in the present paper, which is shown in Figs. 1 to 7, Plates 66 to 70. Fig. 1, Plate 66, is an outside elevation of the furnace to which this system is applied. Fig. 2, Plate 67 , is a vertical section of the same furnace, showing the gas openings A A from the furnace into the neck flue B, and the gas branch pipe with stop-valve $\mathrm{C}$ for connecting or disconnecting this furnace from the range of gas main. Fig. 3 , Plate 68 , is a sectional plan of the furnace taken through the gas openings A A and neck flue B. Fig. 4, Plate 69, is an enlarged section of the furnace top; and Figs. 5, 6, and 7, Plate 70, show a 
vertical section, outside elevation, and sectional plan, of one of the segmental boxes or gas openings.

These gas openings or boxes are made of cast iron, which material has been found to stand very well, and allows of the openings being made so wide that their combined area of passage is amply sufficient for the passage of the gas, without the depth of the opening being more than 15 inches; in consequence of which they do not require

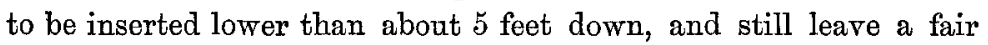
height of 4 feet above them for variation in the level of the top of the materials charged. The boxes are cast very strong, as shown in Figs. 5 to 7, and the openings through them are made at such a slope that nothing except very light dust can be carried through them by the gas in regular working, unless it be a bit of material thrown over by one of the slight explosions that occasionally take place where any raw minerals are used in the furnace. The boxes are placed close together side by side, so as to form a continuous ring of openings round the furnace, as shown in the plan, Fig. 3, having the lower end of the slopes opening into the furnace and the upper end opening into the large external gas flue B, Fig. 4, which surrounds the neck of the furnace. These castings take the place of so many courses of lining bricks, and after they have been fixed the lining firebricks are continued above them to the top of the furnace. Considering their strength and situation, the castings appear likely to be almost permanent. As they stand flush with the face of the lining, the whole area of the throat of the furnace is left free for charging; and when the furnace is full and any portion of the gas passing off at the surface of the materials, no damage can be done to the openings or any part of the gas apparatus. In case of the top of the materials sinking below the gas openings, any damage is prevented by shutting the gas valve $\mathrm{C}$ at once, when the whole of the gas will be burnt at the mouth of the furnace, but without injury occurring to any part of the apparatus, as is unavoidably the case with the wronght iron gas main proceeding from a bell inserted in the top of the furnace.

The large gas flue $\mathbf{B}$ surrounding the neck of the furnace is lined with firebrick, and is $4 \mathrm{ft}$. 3 ins. high to the crown of the arch 
by $3 \mathrm{ft}$. mean width. The outside of the furnace from a little below the bottom of the flue upwards is cased with wrought iron plates, to which is fixed a light iron gallery $\mathbf{D}$ for the convenience of cleaning out the flue $\mathrm{B}$. A series of openings $\mathrm{E} \mathrm{E}$ are made in the outer side of the flue all round, as shown in the plan, Fig. 3, which are closed by pieces of boiler plate daubed with moistened fireclay and held in their places by crossbars and wedges; by means of these the whole of the neck flue can be cleaned out in a few minutes any time that the blast is off the furnace. The bottom of the flue is placed at a lower level than the bottom edge of the gas openings A A, Fig. 4, in order that the dust carried over with the gas may be allowed to accumulate in the flue, so long as it does not interfere with the gas openings, and it can be easily cleaned out when required. Experience of the working of this plan of furnace top proves that, from the increased area of the gas openings as compared with other plans, the gas does not pass nearly so rapidly out of the furnace, and consequently has not the power to carry nearly so much dust into the flue. The sectional plan Fig. 3 shows that there are fifteen gas openings A A round the neck of the furnace, $23 \frac{1}{2}$ inches wide and $11 \frac{1}{2}$ inches high on the square, each giving 270 square inches clear opening, making a total area of 4050 square inches for drawing off the gas ; whereas the single central opening of the bell of $4 \mathrm{ft} .6$ ins. diameter previously worked in the same furnace, which was as large a size as could be conveniently used, gave an area of only 2290 square inches for drawing off the gas, or only 56 per cent. of the area now obtained with the present neck openings. As the gas openings give a total area of 4050 square inches for the passage of the gas, while the descending gas main supplied by them being $4 \mathrm{ft} .6$ ins. diameter has an area of only 2290 square inches, the velocity of the current of gas through the openings is necessarily only half what it would be where a bell or centre opening is used for drawing off the gas, as in the latter case the gas opening to the furnace cannot be made of larger area than the descending gas main of $4 \mathrm{ft} .6$ ins. diameter.

The furnace first put to work on this plan by the writer was started in September 1864; and as fear had been frequently 
expressed previously, that if the gas was taken off from the outside of the furnace instead of from the centre the working of the furnace would necessarily be injured, the work was not done at all substantially at first, but merely with cast iron plates 2 inches thick to form the gas openings, by way of trial. This fear however of drawing off the gas from the outside of the furnace within a reasonable distance of the top, instead of from the centre, appears when fairly looked into to be unfounded. For the gas has to ascend a height of about 40 feet through a furnace filled with considerable sized masses of solid fuel, ironstone, and limestone; and therefore becomes broken up into innumerable separate columns, each of which is again turned in different directions as soon as it meets with another solid obstruction.

Notwithstanding the temporary kind of construction that was adopted for trial in the first furnace, the gas openings made with only 2 inch cast iron plates lasted more than a year, and stood some of the severest treatment that a furnace top can be exposed to, in consequence of a sort of fuel being tried at one time which proved a total failure, and with which the furnace was unable to drive at all; and consequently for two days the whole throat was at a red heat. It was expected that when the furnace did drive below where the openings had been they would be found to have given way. They had not however completely given way in any instance, and though the plates were very much bent they remained at work a great part of a year afterwards. Their standing so well is to be attributed to their position, in the outside of the furnace instead of in the centre; and also to the effect caused by closing the valve on the top of the descending gas main, so that no gas or flame could then pass outwards through the openings, as there was no longer any current to draw the heat through the openings. Had a bell been at work in the centre of the furnace top in this instance, the only way to save it would have been to disconnect it and lift it out entirely; but this could not have been done till the materials in the furnace throat had lowered themselves below the mouth of the bell.

As the gas openings are now cast, as shown in Figs. 5,6 , and 7, it is anticipated they will stand for many years. The repairs also 
seem to be quite nnimportant, for when required it will only be necessary to change the old set of openings or castings for a new set, and the iron in the set taken out will be nearly equal in weight to that put in.

The advantages of this plan of taking off the gas may be summed up as follows.

The whole height of the furnace throat is left free for charging, which is equivalent to giving additional height to the furnace in comparison with other modes of taking off the gas.

The top of the gas openings being 4 feet below the top of the furnace, as long as the materials are kept charged up to within $3 \mathrm{ft}$. 6 ins. of the furnace top no damage can be done by flame to the gas apparatus, except by carelessly allowing the chimney draught to be so strong as to take off more than all the gas and consequently draw in some air from the furnace top.

There is no wear and tear from the shocks of the successive barrow loads of material charged, which do so much damage to a cylinder carried upon brick arches or a bell suspended in the furnace throat.

The whole of the gas apparatus is of simpler construction; and being all placed below the charging platform, it is much cooler and more free for the men to get at. From the large area of the gas openings and neck flue, which allows the dust to be for the most part deposited in the neck flue, the gas apparatus is less liable to become foul; and this neck flue can be cleaned with the greatest ease whenever required.

From the great strength of the castings forming the gas openings and their advantageous situation, next to no repairs are required, and there are consequently fewer stoppages, and an increased make of iron is the result.

There is also the convenience of being able at any time to burn any portion or even the whole of the gas at the furnace mouth without doing any damage to the gas apparatus.

The experience of the working of this plan of taking off the waste gas at the writer's furnaces is very satisfactory as to yield and greater regularity in make of iron, in consequence of there being 
fewer stoppages; whence also there is a great saving of wages. By this plan the desideratum previously mentioned may be very nearly if not quite attained; namely an open-topped furnace where under no circumstances can there be back pressure or the trouble of lifting a charging cone. The ring of openings of 15 inches height, at a depth of not more than 4 feet from the furnace top to the top of the openings, are found able to take off just as much gas as is desired, by opening or closing the gas valve and so only permitting enough gas to escape at the top of the materials to warm and dry them without firing the fuel in the furnace top to any material extent.

In many previous instances the gas has indeed been taken off through the sides of a furnace and into flues in the brickwork of the furnace; but then it has been taken off at so great a depth that its withdrawal from the furnace at so early a period must be injurious; and the openings have been made 3 or 4 feet deep, thereby greatly weakening the structure of the furnace. It is evident that by taking off the gas lower down in a furnace it is taken off under a pressure sufficient to force its way through the materials above that depth, and by this means the gas may be drawn off without so powerful a chimney : but by so doing the working height of the furnace is in effect greatly reduced; and experience shows that in the Staffordshire furnaces at least there is great value in every foot of height that can be worked, while probably a trial would show something valuable in an additional 6 feet of height or more.

Mr. N. Neal Soliy said that he fully concurred with the views advanced in the paper as to the advantages of open-topped blast furnaces over those working with a closed top; and having had several years' experience at the Willenhall Furnaces in taking off the waste gas from open-topped furnaces, by means of a bell suspended in the centre of the furnace throat, he was satisfied that the plan described in the present paper was a great improvement, and decidedly superior to the other modes of taking off the gas, as 
the suspended bell was liable to frequent accidents. He enquired whether the supply of gas obtained by this means was always found as large and as regular as when taken off by the bell previously used, and whether it had always done the work as satisfactorily in the boilers and hot-blast stoves.

Mr. ADDENBROOKE replied that this plan was found even more effective than the bell suspended in the furnace throat; indeed the ring of openings round the neck of the furnace were capable of taking off the whole quantity of gas that the furnace yielded. By the aid of the powerful chimney draught he had seen the gas so completely drawn off that a man had been able to walk across the top of the materials in the furnace throat, whilst the furnace was working at the rate of 220 tons per week: but in this case there must have been air drawn in through the top of the materials by the dranght being unnecessarily strong, which would cause combustion to take place immediately below the surface, where it was very undesirable; and accordingly orders were given to the men that, whenever the flame disappeared entirely at the furnace mouth, the gas valve was to be partially closed until a slight flame appeared again, so as to make sure that no air was being drawn down through the furnace top.

Mr. P. A. Mrulward, engineer at the Rough Hay Iron Works, Darlaston, said that the gas taken off from the furnaces by the system described in the paper had been found to do its work in the boilers and hot-blast stoves quite as well as when taken off by the bell previously used; and the present plan not only gave the means of drawing off much more gas than was required for heating purposes, but also admitted of taking off the whole of the waste gas from the furnace, though that was more than it was desirable to accomplish.

Mr. J. E. SwINDELL enquired whether the heating of the boilers and hot-blast stoves was not interfered with whenever the gas valve was closed on the occasion of the flame disappearing at the furnace mouth.

Mr. AdDenbroore explained that the gas valve was never shut entirely; but whenever the flame disappeared at the furnace top 
the valve was partially closed to a sufficient extent to cause a portion of the gas to pass out at the furnace mouth and restore the flame. Even when the gas valve was partially closed however there was an abundant supply of gas for heating purposes; for the furnace produced always more gas than would be required even with the oldest and least economical forms of boilers. The boilers used at the Rough Hay Iron Works were plain cylindrical boilers without any flues, and they supplied steam to the blast engine, and to the engine employed in the fitting shops and for working the wood-sawing machinery and raising the materials for filling the blast furnaces ; and the whole of the heating was done by the waste gas, without the use of any other firing. An important advantage in the employment of the waste gas for this purpose had been that it had effected a very considerable saving in repairs both of boilers and hot-blast stoves; the boilers and stoves frequently worked for several weeks together without the firedoors being once opened, so that they were not subjected to the constant exposure to expansion and contraction by alternate heat and cold, and consequently the boiler plates and hot-blast pipes lasted much longer before requiring repairs than when heated by burning coal under them; there had indeed been scarcely any repairs required since the waste gas had been employed for heating.

Mr. J. E. Swindelu thought the plan described in the paper was certainly a step in the right direction for taking off the waste gas from open-topped furnaces. In the case of close-topped furnaces, where the whole of the waste gas was taken off, he understood the supply of gas obtained was always found greater than was required for all the purposes to which it was applied; and therefore there seemed no reason to doubt that in the open-topped plan now described a sufficient quantity of gas might always be obtained from the furnace, while still leaving some to burn out at the open top of the furnace. He enquired whether the fuel employed in the furnaces described was all coke.

Mr. ADDENBROOKE replied that since the present plan of taking off the gas had been adopted the fuel employed in the furnaces had not been entirely coke, but a good deal of coal had been used also. 
This had nothing to do however with the mode of taking off the gas, which was equally effective whether coal or coke was employed. In one respect this plan of taking off the gas was certainly invaluable in furnaces where coal was used, as compared with a bell suspended in the month of the furnace; for the flame burning out at the mouth of a furnace working with coal was so much hotter than with coke that the bell and the horizontal branch pipe leading from it became very highly heated, and were greatly injured by the flame; but in drawing off the gas by the neck openings below the surface of the materials, no part of the gas apparatus was exposed to the flame in the furnace mouth, and the whole of the flues and pipes were kept so cool that within a few feet of the neck flue the hand could be held upon the $\frac{1}{4}$ inch plates of which the gas main was composed. Moreover in the case of a bell suspended in the furnace mouth the area of the bell was no larger than that of the gas main, and therefore the full force of the chimney draught acted at the bell, causing a large quantity of dust to be drawn off with the gas; but in the present plan the area of the gas openings round the neck of the furnace was greater than that of the gas main, so that the gas came off quietly through the openings and carried over less dust with it; and the dust was then deposited in the neck flue instead of all passing down the gas main.

Mr. J. E. SwINDELL observed that mention had been made in the paper of a close-topped furnace at Dowlais, from which the gas was carried to a distance of a quarter of a mile before being consumed; and he enquired whether it could be conveyed to as great a distance if required in the mode now described of taking off from opentopped furnaces.

Mr. Addenbrooke replied that in the open-topped furnaces the gas could be taken to any distance, according to the power of the chimney draught, and with the advantage that the working of the furnace would not be affected by any back pressure, whatever might be the distance to which the gas was conreyed. With a more powerful chimney however the gas openings would have to be placed rather lower down in the furnace, so as to avoid drawing in air with the gas. In the case of the close-topped furnace at Dowlais that 
had been named, a portion of the gas taken off was employed near the furnace for burning bricks and calcining ironstone; and the rest of the gas was then conveyed to a distance of about a quarter of a mile to heat the boilers of the forge and rolling mill; but the back pressure produced in the furnace top by forcing the gas along such a length of pipe amounted to $\frac{3}{16}$ inch of water, and he understood it was intended to employ a fan for drawing off the gas, so as to diminish this back pressure on the furnace.

Mr. W. HADEN enquired whether there would not be some difficulty in replacing the castings forming the gas openings round the neck of the furnace, whenever they required renewal; and whether it would not be advisable to make some provision for replacing them readily in the event of any mishap.

Mr. ADDENBRooke replied that with the present strong construction of the castings forming the gas openings, of which a full size model was exhibited, it was not expected that there would be any considerable wear, and there was reason to expect they would last quite as long at least as the lining of the farnace; and as they merely took the place of a few courses of lining at the top of the furnace, they could readily be replaced if requisite at the time of renewing the lining. The durability of the castings would of course depend upon the care with which the furnace was worked, and if there were a flame through the gas openings it would necessarily cause destruction of the iron; but it must be borne in mind that when the working was properly managed, so that a flame was always kept burning out at the furnace top and the loading of the materials kept up to the proper height above the gas openings, the gas was drawn off through the openings without any flame, because no air was then drawn down from the top to produce flame below the surface of the materials ; and consequently the castinge were not exposed to injury from the passage of the gas through the openings. Even the first gas openings, constructed of only 2 inch cast iron plates, as a temporary expedient by way of making trial of the new plan, had continued satisfactorily in work for upwards of a year, notwithstanding the very severe test to which they wore subjected within three months of being pat in, 
when the whole throat of the furnace had been at a red heat for two days; and the present castings were so much more massive that they were expected to prove much more durable. On the occasion of putting in the new castings in the second furnace to which the plan had been applied, which had been done about nine months ago, advantage had been taken of an opportunity when work was slack; and the blast being tnrned off, the furnace stood six days with the charge in it while the top was taken down sufficiently far to put in the new set of openings, after which the working was continued again without any inconvenience resulting from the stoppage. At present there had been only nine months' actual experience of the durability of the castings; they did not show any injury, and whenever they might require renewal, the cost of replacing them would not be serious, as the iron originally put in would be nearly all recovered in the old castings taken out.

The Chatrman remarked that as the ring of gas openings round the neck of the furnace was composed of separate segmental castings, he presumed it would be practicable at any time to replace a single defective casting without much difficulty; and he enquired what was the weight of each of the castings, and whether they were placed contiguous to one another all round the circle, or whether there was anything interposed between the successive segments.

Mr. ADDENBROOKE replied that the castings weighed nearly 1 ton each, and were placed close together round the furnace throat without anything between them; and for taking out any one of the castings it would only be necessary to take down the furnace top immediately above that particular casting, so as to allow of lifting it out by a crane and putting in another casting in its place.

Mr. C. P. SANDBURG remarked that the atilisation of the waste gas from blast furnaces had been clearly proved to be beneficial, even where fuel was cheap; but the difficulties by which it was attended, namely irregularity in the working of the furnace, increased consumption of fuel per ton of iron produced, and liability to explosions, had to be carefully guarded against, otherwise the result would be a loss instead of a saving. 
On the Continent and in Sweden the waste gas had been utilised for twenty to thirty years past. In Sweden Professor N. G. Sefstrom, of the School of Mines at Fahlun, had been the first to employ the gas for the calcining kilns and hot-blast stoves. The gas was taken off through an opening in the wall of the furnace about 5 feet below the top, and the furnace top was left open. The hot-blast stove was placed at the level of the furnace top; and the calcining kiln was also placed in a high position, in order that the gas might not have to be drawn down to a much lower level, which was to be avoided on account of the small pressure of the gas. In some places a vertical cylinder of nearly the same diameter as the furnace mouth was inserted in the top of the furnace, for taking off the gas from the top, thus obtaining a higher pressure; while the surplus gas was allowed to escape through the annular space between the cylinder and the furnace wall. This plan had been applied to charcoal furnaces with but little difficulty, so long as the gas was not required to be drawn down from the furnace top to a lower level; but considerable difficulties had arisen when the fireplace where the gas had to be burned was situated down at the level of the tuyeres, in which case the necessary power for drawing the gas down had not been obtained even with the assistance of an ordinary large chimney; and the result had been a greater consumption of fuel in the furnace instead of a saving. In order to ensure the gas being drawn down, it had been found advantageous to have a pressure of gas in the tube of not less than $\frac{1}{2}$ inch of water at the furnace top and 1-10th inch near the fireplace at the level of the tuyeres.

In conveying the gas through tubes from the furnace top to the fireplaces it was found better to have a positive pressure or plenum inside the tubes; so that the small openings for leakage round the valves, which could scarcely be avoided, might allow the gas to escape, instead of drawing air into the tubes. In the fireplace also the combustion was better effected when the gas was delivered there by pressure than when drawn down by means of a draught. It had also been found necessary to avoid the horizontal gas tube at the top of the furnace, because it was liable to become filled up with dust deposited there from the gas taken off; and it was desirable to 
conduct the outer end of the gas tube into a water cistern, which acted both as a receptacle for dust and also as a safety valve.

In coke furnaces the means of obtaining the requisite pressure in the upper part of the furnace for forcing the gas down from the furnace top had generally been by working the furnace with a closed top; but in charcoal furnaces the charge itself acted as a sufficient cover to close the furnace top, the ore being crushed to a fine state; and in these furnaces therefore it was sufficient to lower the opening for the escape of the gas, while the furnace top was left open. The close-topped furnaces were worked in many localities in England and on the Continent, while the open-topped furnaces were employed in some parts of France, Germany, and Sweden; and in the Swedish furnaces charcoal was used exclusively. In the case of six open-topped charcoal furnaces in Sweden of which he had had the management from 1856 to 1860 , the hot-blast stoves were removed from the top of the furnaces down to the level of the tuyeres, and the necessary pressure of the gas was obtained by lowering the gas opening down to 14 feet below the top, the height of the furnaces being 42 feet. No chimney was used in connection with the stoves, and no loss of fuel or other objection was caused by taking off the gas so low down in the furnace.

In the plan described in the paper for taking off the waste gas, the use of a chimney draught for drawing down the gas from the furnace top had been carried out to a much greater extent than he had ever seen successfully accomplished before, the gas openings being only 4 feet below the furnace top, which was left entirely open, and the gas being drawn down to the level of the tuyeres entirely by the force of the chimney draught. Such an arrangement appeared a retrograde movement in the principle of taking off the waste gas; but having had the pleasure of seeing the working of this plan at the Rough Hay Furnaces, he had found that it proved completely successful in practice. The supply of gas at the boilers appeared to be plentiful, and the combustion was well regulated; and the whole arrangement was well worthy the attention of every one connected with the working of blast furnaces. He thought however that with the gas openings' situated at only 4 feet depth 
below the open furnace top, and with such a large chimney for drawing off the gas, there would be need of special care to keep the furnaces at all times well filled and regular in the level of the charge; otherwise air would be drawn down from the top, and entering with the gas into the pipes would cause explosion. The reason assigned for placing the gas openings so near the top of the furnace was that the consumption of fuel had been found to be increased when the gas was taken off at a lower level; but in this respect the experience of the furnaces referred to in the paper differed from that of the Swedish charcoal furnaces, as well as the Continental coke furnaces, where the gas was taken off at a much greater depth below the top withont increasing the consumption of fuel.

Mr. AdDenbrooke observed that, though the use of a chimney for drawing off the gas from the blast furnace appeared to be little known in connection with the Swedish furnaces, it was by no means new in this country, having been employed previously for furnaces in Staffordshire, as well as in the Yorkshire and Welsh districts. The level at which the gas was drawn off from the furnace had been found in his own experience to be an all-important point; and he did not understand how this could have been found a matter of indifference in the Swedish furnaces.

As regarded the liability to explosion in taking off the gas by the mode described in the paper, he had not found there was any liability to explosion unless through gross carelessness and mismanagement. In Sweden he understood there had been several explosions, and nine or ten hot-blast stoves had been split by explosions; and he thought this was to be accounted for by the plan of taking off the gas, having a plenum of pressure to force the gas down from the furnace top, instead of a chimney draught to draw it down; so that, whenever the stoves were standing idle, there was a liability of some gas being still forced into them through the leakage of the valves; and as there was no draught to carry it off, this would hang in the top of the stoves and form an explosive mixture with the air, and then an explosion would ensue when a light was applied to it. But with the chimney dranght as 
employed at his own works, the regulations were that the draught was always to be put on the stoves before the gas was admitted, so that there was no opportunity for any explosive mixture to be formed; and he had accordingly had scarcely any accidents by explosion in the use of the waste gas for the boilers and hot-blast stores.

Mr. JOHN JoNEs enquired whether in taking off the waste gas by the plan described in the paper the production of pig iron by the furnaces had been greater or less than before the gas was taken off.

Mr. ADDENBROOKE replied that the production of pig iron had certainly been found to be increased since the waste gas had been taken off, the make of each furnace having now got up to more than 200 tons per week, instead of the former make of only 150 or 160 tons per week. He did not consider however that the whole of this increase of make was to be attributed to taking off the waste gas, as he thought it was partly due to the use of the new gunmetal toyeres, which had recently been adopted for blowing the furnaces, and which formed the subject of another paper at this meeting. Another advantage which had been experienced was that the quality of the iron made was very much more regular than before the gas was taken off from the furnaces.

The Chatruan moved a vote of thanks to $\mathrm{Mr}$. Addenbrooke for his paper, which was passed.

The following paper, communicated through Mr. Addenbrooke, was then read:- 
BLAST-FURNACE WASTE GAS. Plaze 66.

Fig.1. Elevation of Open-topped Blast Furnace

at Hough Hay Iron Works, Darlaston.

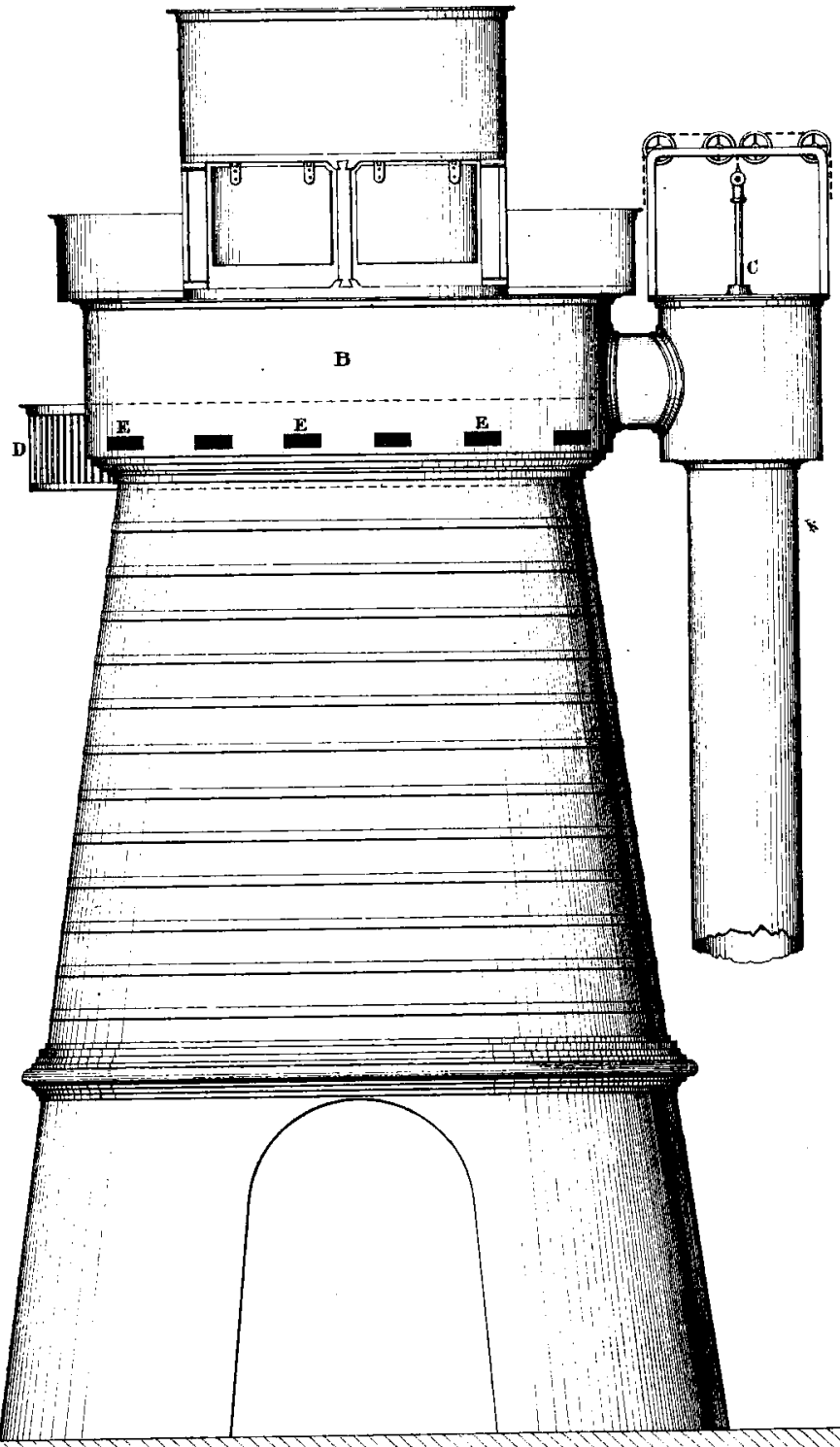

(Proceedings Inst. M.E. 1865. Page 235.)

10

Scale $1 / 120^{\text {th }}$

Downloaded from pme.sagepub.com at University of Bath - The Library on June 5, 2016 
BLAST-FURNACE WASTE GAS. Plate $6 \%$.

Fig.2. Vertical Section of Open-topped Blast Furnace at Rough Hay Iron Works, Darlaston.

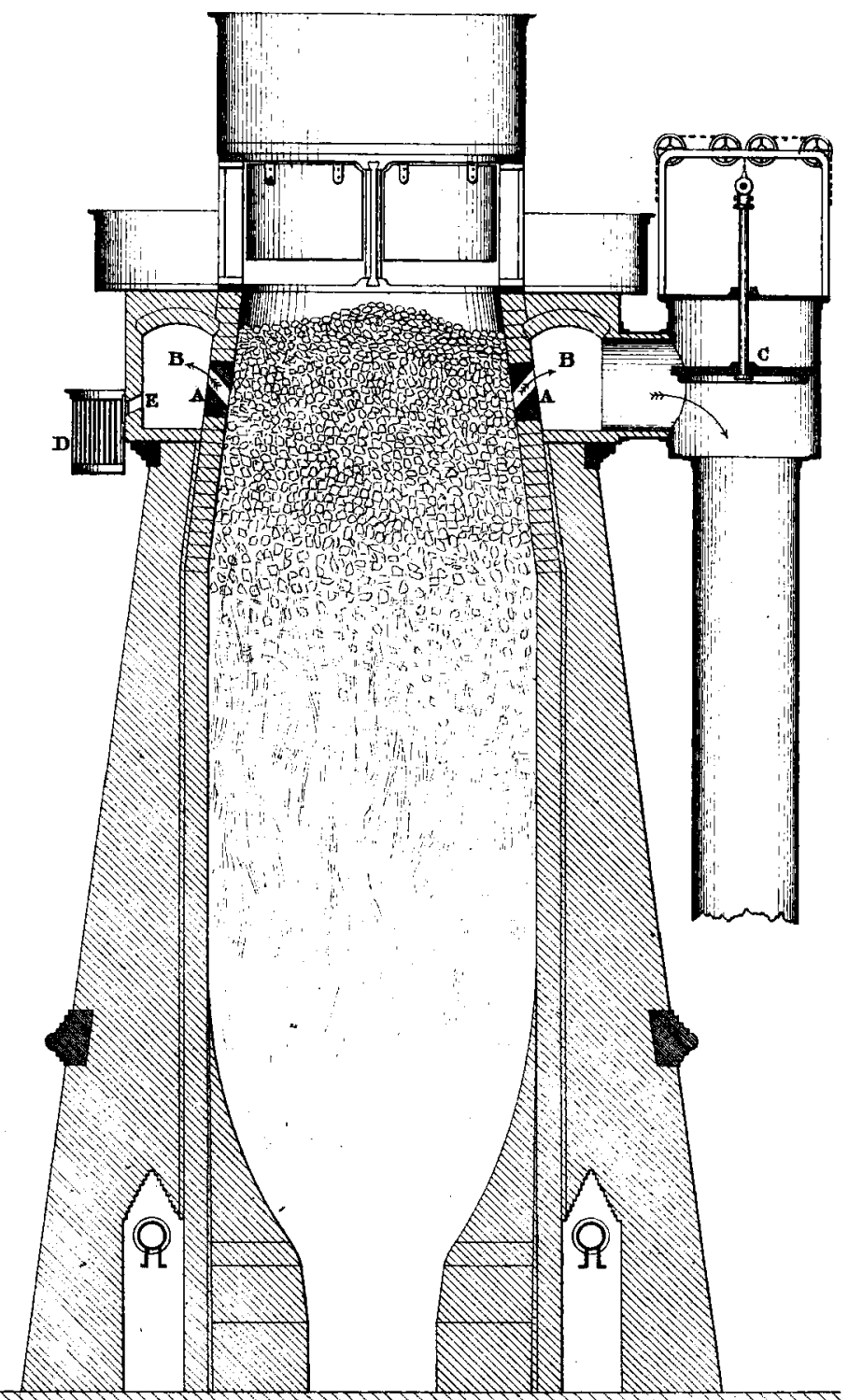

(p)

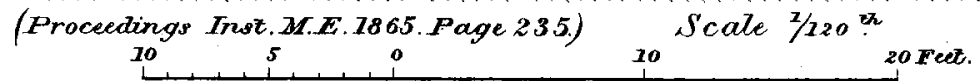




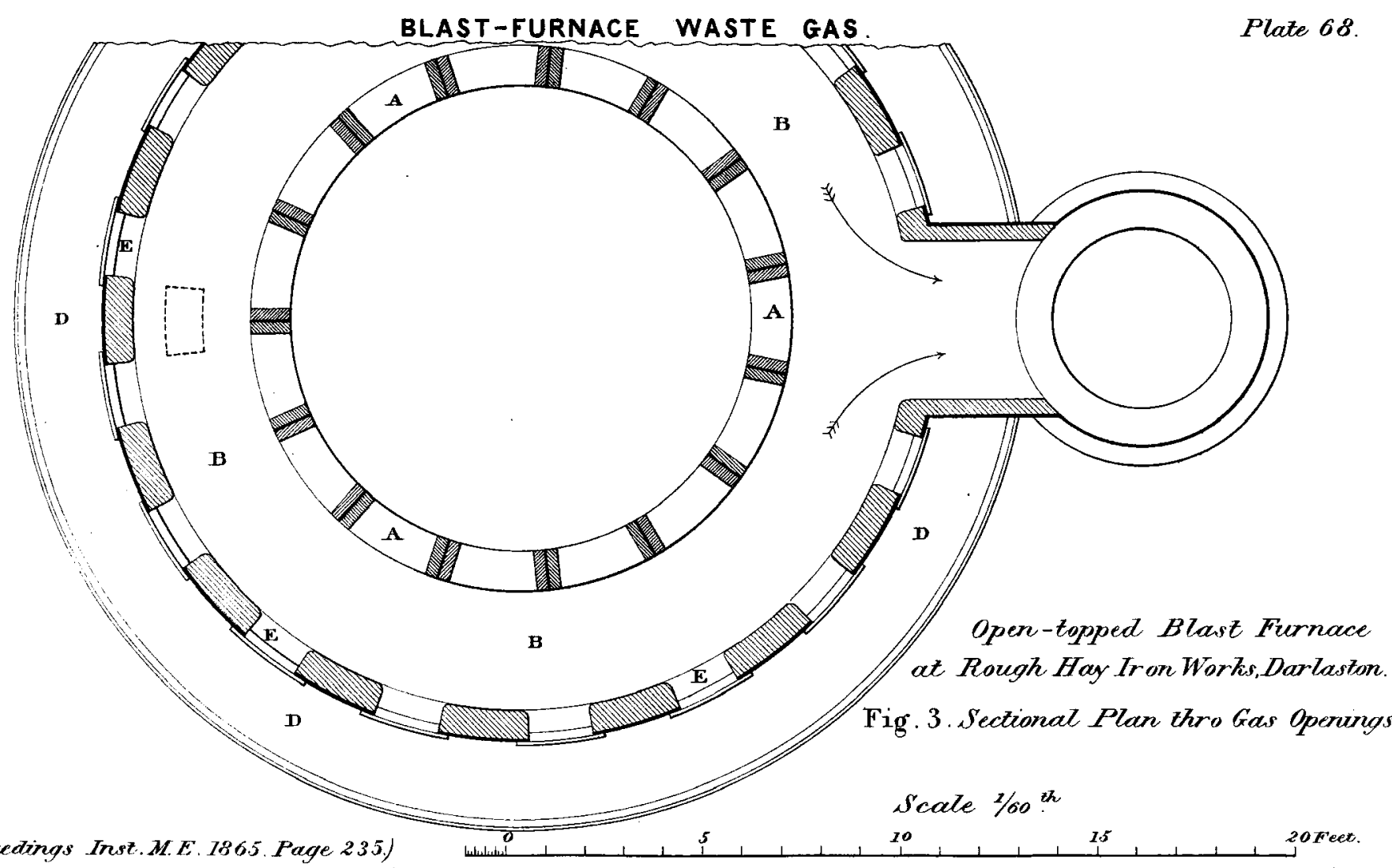


BLAST - FURNACE WASTE GAS.

Fig. 4. Enlarged Section of Open Top of Blast Furnace at Rough Hay Iron Works, Darlaston.

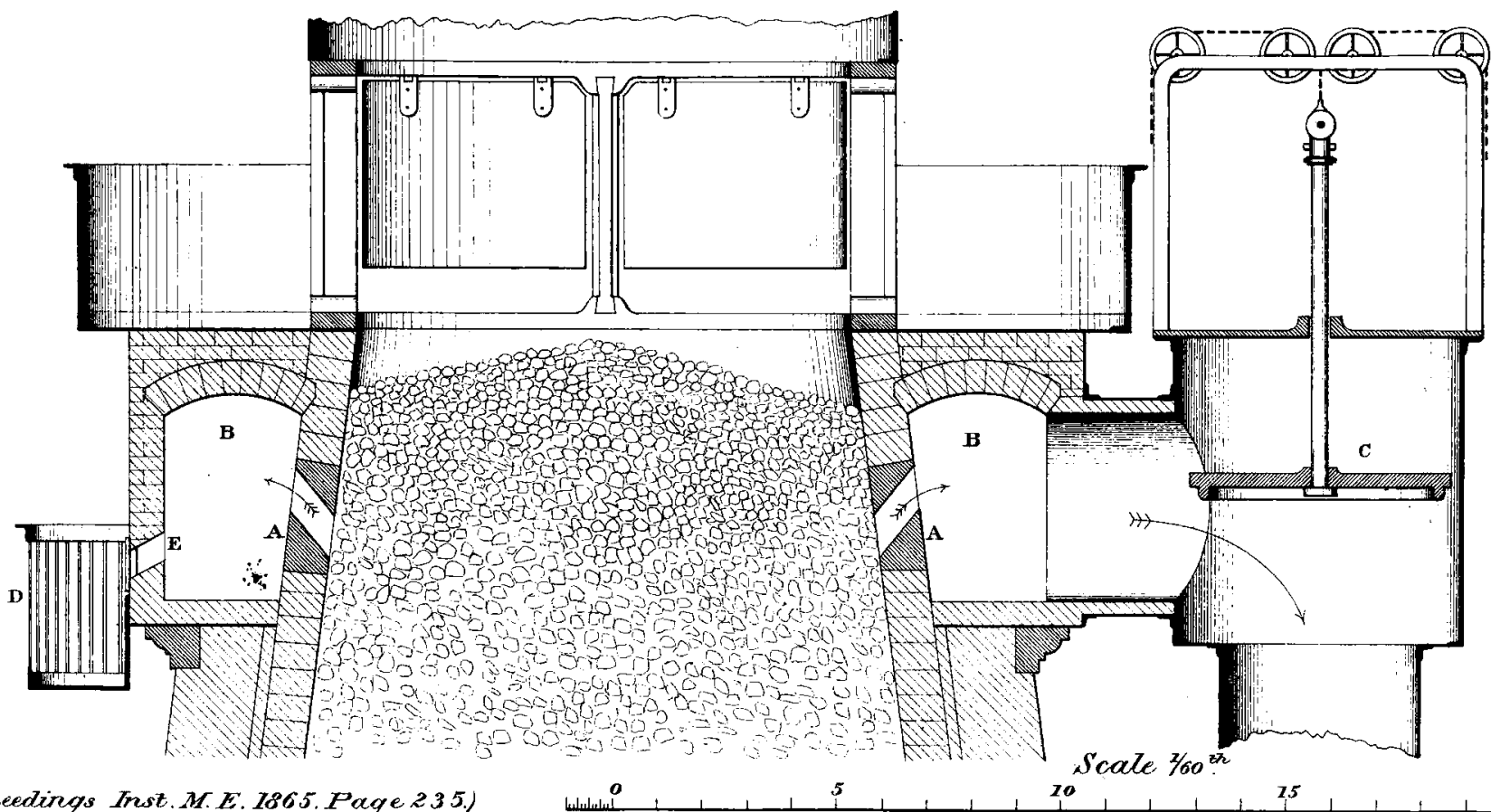


BLAST - FURNAGE WASTE GAS.

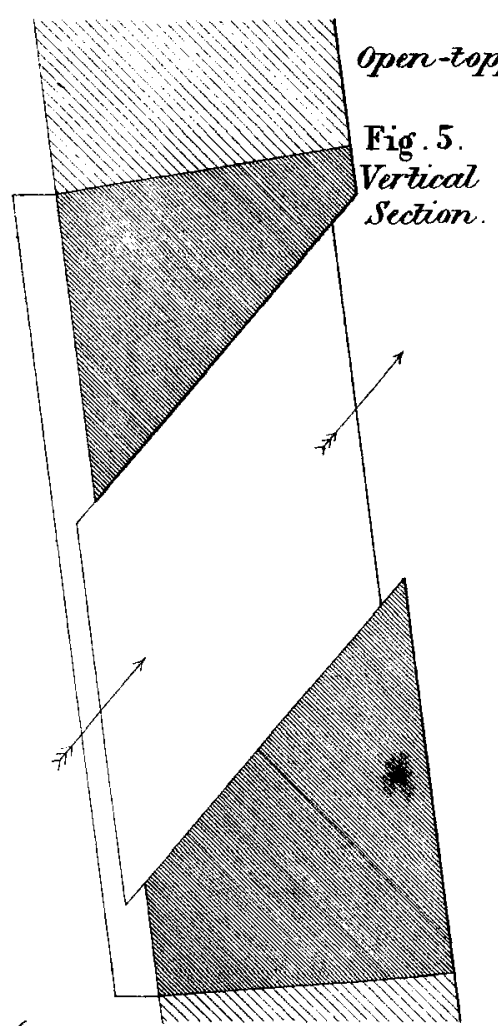

B Blast Furnace at Rough Hay Fron Works, Dartastan Detail of Cowtings for Gas Openings.
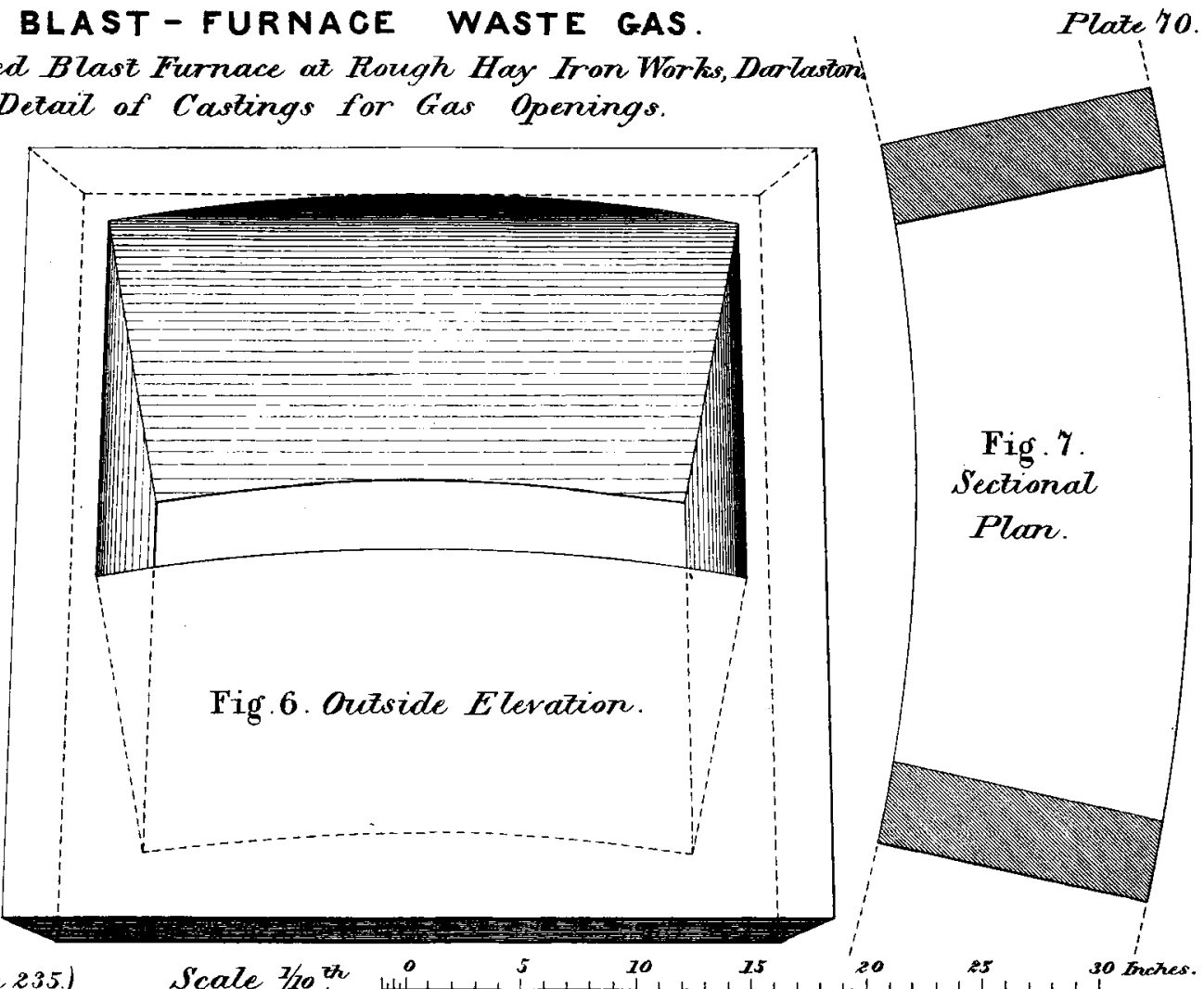